\title{
THE SOCIAL CONSEQUENCES OF RIVER BASIN DEVELOPMENT
}

\author{
Card F. KRaENzeL*
}

I

INTRODUCTION

Why is the United States concerned with river basin development? Does it need greater industrial and agricultural production than is potentially in prospect? This is hardly the case, except, perhaps, taking an extremely long-range view. Does it face difficulty in supplying the necessary livelihood for its anticipated population for the next quarter of a century? This, too, is inconceivable. Does it need more urbanization and a greater concentration of its population? This, also, is insupportable, although a case can, perhaps, be made that too many of our cities and too much of our urban population are located in too circumscribed a part of the nation for its fullest and most balanced over-all development.

The nation's concern with river basin development, it is submitted, is rather largely socially motivated, stemming from a desire to provide a more equitable and favorable economic and social climate for all of its citizens. For, it has been recognized that such development is an effective instrument for the conservation of resources, human and otherwise. It affords the controls needed to keep water, soil, and vegetation in place and at a high level of production, so that Americans of today and tomorrow. will continue to enjoy an increasingly rising standard of living. It gives greater assurance of maximum utilization of power, irrigation, and other natural resource potential. And, perhaps most significantly, it imports a change in social values, emphasizing not only the natural-resource-conservation and individualwell-being points of view, but also the need for creating a greater, more pervasive social responsibility, extending over increasingly larger geographic areas and encompassing rural-urban differences and hinterland-metropolitan interdependence.

River basin development, thus, has been undertaken to bring the productivity of some underdeveloped areas in the nation more nearly into line with that of their more highly developed neighbors. Owing to the multifaceted character of river basin development, it has been possible to arrest progressive deterioration of resourcese.g., erosion and flooding - and to encourage new economic opportunities-e.g., hydroelectric power, irrigation agriculture, industrial expansion, new resource utilization, and recreation-with the result that income and employment have been increased

*A.B. 1930, University of North Dakota; M.A. 1932, University of Minnesota; Ph.D. 1935, University of Wisconsin. Professor of Rural Sociology, Montana State College. Social Science Research Council Fellow, Harvard University, 1932-33; Consultant on Rural Credit and Cooperatives in Iran for the Near East Foundation, 1954-55. Author, The Great Plains in Transition (1955). 
and stabilized in areas that previously had been underdeveloped or had actually retrogressed and become nearly static. This emphasis upon the more balanced development of all the parts of the nation, moreover, has, to some extent, probably also arrested the appearance of slum areas, discouraged unnecessary population migration with its accompanying problems, and thus further contributed to the total welfare of the nation. Again, the major social consequence of this has been a change in value judgments, a strengthened belief in man's ability to manipulate his environment to improve his living standard.

Above all, then, it would appear that river basin development in the United States is symbolic of greater social justice, greater opportunity for individual self-development and realization, both economically and socially, everywhere in the nation, but particularly in disadvantaged areas. Viewed somewhat differently, river basin development is aimed at curbing the exploitation of one area by another and at introducing a greater measure of economic and social, as well as political, democracy than now prevails in the nation.

In order fully to appreciate the social role of river basin development, it is necessary to understand that the United States has become a highly urbanized, commercialindustrial society. This means that a few metropolitan centers tend to dominate and appropriate other urban centers and all the land, resources, and population of the nation. Bogue has demonstrated that there are only sixty-seven such metropolitan centers of dominance in the United States and that this is simply part of a historical evolutionary process in the course of which an ever-larger hinterland is tied to the center. ${ }^{1}$ Gras, too, recognized this process; ${ }^{2}$ and McKenzie described it in great detail. $^{3}$ Bogue, however, has refined the idea more specifically by showing that not all large cities are metropolitan in character, in the sense that they dominate, and that some larger centers are as subservient to the dominant city as many smaller communities and the purely rural or agricultural resource areas. ${ }^{4}$

The social significance of this phenomenon is that the dominance of metropolitan centers over the hinterland area is largely a one-way, metropolitan-to-hinterland, communication avenue and that it has been a random, accidental, unplanned process, one that has come to encompass increasingly more territory, people, and other larger centers. In this process, there has been an expansion of metropolitan influence and activity beyond local city, county, and even state borders and an appropriation of

\footnotetext{
${ }^{1}$ Don J. Bogue, The Structure of the Metropolitan Community, A Study of Dominance and SUBordinANCE especially I6 et seq. (1950).

${ }^{3}$ Gras traced the relation of the hinterland to the center through the following stages: ( 1 ) the collection economy, (2) the cultural nomadic economy, (3) the settled village economy, (4) the town economy, and (5) the metropolitan economy. Although each stage has increasingly released man from dependence upon the local economy, it has made him progressively more dependent upon an ever-widening area. N. S. B. Gras, AN Introduction to Economic History (1922).

${ }^{3}$ McKenzie, applying the ecological approach to urban phenomena, described the specialization and interdependence of cities and the interrelationship of their parts into an integrated whole and ascribed to this complex the idea of a supercommunity. R. D. McKenzis, The MEtropolitan Community (1933).

- Bogue, op. cit. stipra note I, especially ce. 2-9.
} 
resources and people, all without benefit of democratic participation on the part of the residents of the hinterland. For, other than metropolitan-area planning districts and interstate compacts, there is now no truly democratic political device whereby the residents of the hinterland, and even large segments of the metropolitan residents, can participate in the decision-making that would make of such an area a community, or at least a cohesive political unit. This failing is a serious affront to democratic institutions and to the spirit of democracy itself.

Whatever else the need in the United States, therefore, a compelling task for the future is the curbing of this exploitation of the hinterland by the metropolitan center. This requires the introduction of a mechanism for insuring the democratic participation in decision-making by all the people, whether they live in or near the center or in the far hinterland of the metropolitan areas that comprise the total urbanized, commercial-industrial society of the nation..$^{5}$ And basin development, because of its success in the Tennessee River Valley and because of the absence of other satisfactory models, is the pattern that is generally proposed in the United States for the initiation and the fulfillment of this task.

Before evaluation of river basin development in this context is attempted, however, the following classification of social consequences is indicated:

I. those involving people as individuals and in group relationships on a more-orless local level; and

2. those involving a larger area of interaction, the ever-widening area of economic and social intercourse beyond the boundaries of traditional local government, the more nearly regional level.

And two specific types of situations that must be analyzed, with respect to these social consequences, are:

I. those wherein the river basins have within or close to their confines existing metropolitan centers, including metropolitan centers of dominance, such as the Tennessee River Valley; ${ }^{6}$ and

2. those wherein the river basins do not have within or close to their confines existing metropolitan centers, including metropolitan centers of dominance, such as the Missouri River Valley.

It is the purpose of this paper to show, by focusing on the Tennessee and Missouri

${ }^{8}$ See R. E. Dickinson, City Regions and Regronslism especially 3, 4, 6, 105-07, 245-46, 249-53, and c. 9 (1947). See also Howard W. Odum and H. E. MoOre, American Regronalism especially 3-5, 9-13, 143-50 (1938); Davidson, Political Economy of Regionalism, 6 AM. Rev. 410, 430-32 (I936); Brocard, Regional Economy and Economic Regionalism, I62 ANsals 8I (I932); Davidson, Political Regionalism and Administrative Regionalism, 207 id. at $\times 38$ (1940).

- A study of the metropolitan facts and the location of basins would indicate that other river valleys most like that of the Tennessee are: the Ohio; the Potomac; the Alabama-Coosa; the Connecticut; the Central Valley of California; the St. Lawrence; the Mississippi, as a whole or segmented into the upper and the lower; and certain others. For more extensive details, see 2 President's Water Resources POLIC: CoMm'N, Report (I950).

${ }^{7} \mathrm{~A}$ study of the metropolitan facts and the location of basins would indicate that other river valleys most like that of the Missouri are: the Rio Grande; the Arkansas; the Red River of the South; the Brazos; the Columbia; the Colorado; and certain others. For more extensive details, see ibid. 
River Valley situations, that the nature and the magnitude of the social consequences of river basin development necessarily depend on the peculiar context in which the development transpires. From this, there follows the corollary that where river basins have no metropolitan centers within or close to their confines, their development will not necessarily result in increased social justice and democratic participation-it may, indeed, exacerbate existing patterns of exploitation-unless accompanied by true regionalism. ${ }^{8}$ Such, in fact, may also be true of situations in which the river basins have metropolitan centers within or close to their confines; ${ }^{0}$ but failure to achieve social justice and democratic participation there would be attributable to reasons other than the absence of an indigenous metropolitan influence.

\section{II}

\section{The Tennessee River Valley}

The TVA has become world-renowned as a model of integrated and coordinated development on a river basin level. Greater economic opportunity and social justice have come to the residents of the Tennessee River Valley with the initiation of the program; ${ }^{10}$ and the advances have not been confined to material spheres alone, but have extended as well to leadership development, community enrichment, and intercommunity and interagency cooperation. ${ }^{11}$

Actually, the development of the Tennessee River Valley has occurred on three geographic levels and demonstrates how ramifications from a center of activity may encompass adjacent areas. First, there is the valley proper, containing three and one-half million people, spread out over 40,9ro square miles, resulting in an average density of eighty-five persons per square mile, as compared with an average density of fifty-one persons per square mile for the entire nation. Next, there is an area twice as large, containing six million persons, served by TVA-generated electricity, distributed through municipally-owned or rural cooperative systems and some large

\footnotetext{
${ }^{8}$ By regionalism, the writer does not mean metropolitan planning areas, nor interstate compacts or interagency committee organizations, nor a valley-authority type of region, but rather a distinctly new type of social organization through which the people of areas larger than a state, or portions of scveral states, or a city and the surrounding rural area can participate democratically, politically and financially, in the necessary area development. It is not provincialism, nor is it the separatism of the past. It stresses cooperation among the several political units in the region and between the regions. It does not need boundaries, except for general identification, but it requires a central organization for the area involved where decisions can be made, the execution of which can be assigned to the existing county, state, town, and city political units. For a more detailed analysis of this concept of regionalism, see CarL F. Kraenzel, The Great Plains in Transition cc. 25 and 26 (1955).

- This qualification is introduced because the writer feels that, eventually, river basin development will prove inadequate to the task of introducing and maintaining social justice and democracy in metropolitanhinterland relations even in the small basins which already have indigenous metropolitan centers. For a time, of course, river basin development alone may relieve the tensions, but here, too, the new device of regionalism must inevitably prevail.

${ }^{10}$ For an exhaustive enumeration of the more tangible accomplishments of TVA-engineering, industrial, and economic-see "Progress in the Tennessee Valley (1933-52)," Hearings before the Stubcommittee to Study Civil Works of the House Commitee on Public Works, 82 Cong., 2d Sess. (1952).

${ }^{11}$ This is symbolized by the titles of revealing books by two well-known former TVA board chairmen. David E. Lilienthal, TVA, Democracy on the March (1944); Gordon R. Clapp, The TVA, An Appronch to the Development of a Region (I955).
} 
industrial users. The third area includes all of the seven states-Tennessee, Alabama, North Carolina, Virginia, Georgia, Kentucky, and Mississippi-which, by virtue of having all or part of their territory within the drainage basin of the Tennessee River, have felt the impact of its development in varied degree. ${ }^{12}$

Within this last-mentioned seven-state area are to be found twenty-six of the nation's 168 standard metropolitan areas, as defined by the Census, ${ }^{13}$ with an aggregate population of about six and one-half million. This would indicate that these metropolitan centers are among the smaller ones in the nation; yet, certain other large metropolitan centers are nearby. Nine of the sixty-seven metropolitan centers of dominance, as defined by Bogue, are within the basin states. ${ }^{14}$ Three of them, all in Tennessee, are within the basin proper-Chattanooga and Knoxville on the Tennessee River itself, and Nashville on a tributary, the Cumberland River; the other six are Louisville, Kentucky, Atlanta, Georgia, Birmingham, Alabama, Richmond, Virginia, Charlotte, North Carolina, and Memphis, Tennesseee. In addition, such other cities as Cincinnati, Ohio, and Evansville, Indiana, are not without influence in the Tennessee River Valley area. The basin, therefore, has had ready access to metropolitan forces and resources in aid of its development.

Most significantly, however, the Tennessee River Valley is located in the humid part of the nation, and it is this basic resource and climatological fact, along with urbanization, industrialization, and metropolitanism, that forms the dominant core of the spirit of economic and social development in the United States. ${ }^{15}$

The items enumerated in Table I describe the kinds of social consequence that appear to have accompanied basin development in the Tennessee River Valley and, to a varying degree, in the several states in which the influence of this development has been felt. A more detailed description of each item would be cumbersome at this point and can, moreover, readily be obtained elsewhere in the literature. But from even this cursory catalogue, it is clear that expansion of economic and social opportunities has ranged from improved initiative and choices for individuals, through awakened local community action of all degrees, to functional cooperation among states and between state and federal agencies. Nor can there be any doubt that the resultant social change has been extensive, as is readily apparent from the details of the case-history analyses of situations for persons, communities, institutions, towns, and agencies in the area. There have been pro and con views on many issues raised, of course, but compromise solutions have generally been achieved, owing to an increased measure of cooperation among groups and interests that would otherwise have conflicted or functioned in isolation. There have also been problems that have flowed from this closer association of people, such as is being evinced by the present antidesegregation struggle in Clinton, Tennessee. All this was to have been expected.

\footnotetext{
${ }^{12}$ See James Dahir, Region Building 13 (1955).

132 U. S. Bureau of the Census, Dep't of Commerce, Census of Population: i950, pt. $x$, c. C, at 27-31, and Table 27, id. at 1-72-x-73 (1953).

14 Bocue, op. cit. supra note 1 , at $16-\mathrm{x} 7$.

${ }^{16}$ For a fundamental contrast between this humid, forest-land situation, on the one hand, and the semiarid, treeless Great Plains, on the other hand, see Walter Prescott Webe, The Great Piains (I93I).
} 
Table I-Area of Action Involving Social Consequences in Which Basin Development in the Tennessee River Valley Has Made a Significant Contribution"

r. For the individual, increased opportunities for advancement in educational, occupational, living standards, and social participation matters, including the extension of such opportunities to all economic levels, regardless of race (i.e., including Negroes).

2. To actually motivate individuals and groups, an enhanced psychology of optimism, with reasonable assurance that these things would come to pass.

3. To assist individuals and groups, the development of leadership on a local level, such as extension agents, agency workers, teachers, farmers, and businessmen on all levels. This was done by involving these people in the actual participation of the program, with a training program for leadership development, if necessary.

4. For community development, the involvement of local people on a community and intercommunity level, with leadership, technical, and financial assistance from outside, if necessary.

5. For institutional development and expansion, the involvement of local agencies and institutions, such as the library extension program, the improvement and consolidation of schools and churches, the promotion of public health services, and the introduction and extension of cooperative enterprises, such as rural electrification associations.

6. For coordination and cooperation among like and different institutions and agencies, the involvement of these into larger-than-traditional areas of operation, including the involvement of counties across state boundaries.

7. For town building, the encouragement of businessmen to introduce new businesses or extend and improve existing services, even to the extent of giving a new look by facelifting of the main streets.

8. For pride and self-esteem, a reforestation and beautification program for homesteads, town sites, recreation sites, and farm and field appearances. In addition to providing new employment, economies, and efficiencies, this built a morale that was supported by public consensus and encouraged others to conform.

9. For better understanding and a larger view, research and planning information carried on, often with local help and encouragement, resulting in a more effective incorporation of this new knowledge into the operations of the program.

Certain major conclusions concerning the social consequences of basin development seem to be inferrable from the Tennessee River Valley experience:

I. Improvement of individual welfare, community organization, institutional growth and coordination between functions and between areas can come about most easily and with greater chances of success when there is help from outside-from outside the individual and from outside the area.

2. Such outside help is most productive if it is based on knowledge and understanding that research and planning can provide.

3. This help and knowledge is most productive if it is made available on the "grass-roots" level, so that people, communities, and agencies can husband these things to themselves as their own.

* This classification is one drawn up by the writer in an attempt to inventory and summarize the kind of sociological phenomena, action, and consequence that occurred in the Tennessee River Valley, not solely because of basin development, but certainly with its encouragement. This classification, although distilled from many publications, does not purport to be exhaustive. 
These are fundamental social-action principles that have been clearly identified and recommended for any action program. They have unequivocally been recognized, encouraged, and successfully applied by the TVA administration. The end product, as social consequences, could, therefore, not help but be constructive and beneficial.

But there must be a final warning. How much of this success in achieving desirable social consequences is attributable primarily to river basin development, and how much to other factors? As has been indicated, the TVA area does contain metropolitan centers and is close to others-spatially, economically, industrially, and socially. It always has been, and still is, more nearly a part of the urban-industrialtechnological complex than of the area that has been dispossessed and discriminated against by the metropolitan concentration typical of American society today. It is a part of the American interior, behind the first range of mountains, that forms the base of an America prepared for war or peace-and so is in a state of optimistic expansion. Thus, it is clear that integrated development of the Tennessee River Valley, now past the quarter-century mark, transpired in optimal surroundings.

On the other hand, however, it is also apparent that development of the Tennessee River Valley provided much outside leadership and aid to individuals and communities in their efforts to achieve a fuller self-realization. Nor can there be doubt that the policy aims and leadership of the TVA administration were "socially aware" and "democratically" inclined; nor that this leadership deliberately experimented with the available tools and knowledge. ${ }^{16}$ Consequently, although factors other than river basin development may have been instrumental in effecting the favorable end result, this should not detract from the TVA experiment and the magnitude of its contribution in this regard.

That the TVA's success in achieving desirable social consequences can be duplicated in other river basins similarly favored by the presence of the peculiar urban, industrial, and technological structure typical of metropolitan dominance and concentration is a highly probable fact. That such consequences will follow in river basins that are without or denuded of such urban, industrial, and technological structure, however, is still to be determined. The testing ground is likely to be the Missouri River basin.

\section{III}

\section{THE Mrssouri River VALLEY}

The Missouri River Valley contains 530,000 square miles, thirteen times that of the Tennessee River. The longest straight-line distance spanning the basin is 1500 miles. Much the larger part of it is of arid or semiarid mountain or plains topography and climate, and only the eastern part, east of the ninety-ighth meridian, is subhumid or humid, more nearly like the Tennessee River Valley's climatic conditions. ${ }^{17}$

${ }^{10}$ See generally LILIENTHal, op. cit. supra note II; CLAPP, op. cit. supra note II.

${ }^{27}$ See Missouri Basin Survey Comm'n, Missourt: LaNd and Water (1953); Ickes, Missouti River Basin, S. Doc. No. Igr, 78th Cong., 2d Sess. (I944). See also 2 Prestdent's Water Resources Policy Covar's, op. cit. supra note 6 . 
Whatever other contrasts may be drawn between the Tennessee and the Missouri River Valleys, however, two stand out graphically. The first is the industrial underdevelopment and arrest of population growth in the upper Missouri River Valley, occasioned by the absence of indigenous urban, industrial, and metropolitan influences, which are concentrated rather in the southern and easternmost (and most humid) parts of the basin or impinge on the basin from the outside. The second major contrast between the Tennessee and Missouri River Valleys is the lack of adapted institutional and cultural traits and patterns in the Missouri River Valley except, perhaps, for some of the ways of agriculture. The way of life in the upper Missouri River Valley, west of the ninety-eighth meridian, is an insecure one, because it has been shaped by a nonobjective, humid-area bias and, accordingly, is not suited to the conditions of semiaridity that prevail there..$^{18}$ Agriculture, in parts of the basin, has made certain suitable adaptations, but owing to the lack of urban-metropolitan complexes that are properly oriented to and might be foci for such development, there has been only limited dissemination of even such practices. Furthermore, there has been virtually no similar adaptation of the remaining political, financial, business, economic, and social institutional structure. And this vitally affects the lives of all the residents, the farmers and ranchers included.

More detailed reference, perhaps, should be made to the lack of metropolitan influences in this area. Eighteen of the total of 168 standard metropolitan areas, as defined by the Census, are located within the borders of the ten states that are wholly or partially drained by the Missouri River system, although only seven of these centers are in the basin proper. ${ }^{19}$ Of these seven, moreover, only one-Denver, Colorado-is located in the semiarid portion of the basin, the mountainous southwestern part; the six others-Sioux Falls, South Dakota, Lincoln and Omaha, Nebraska, Sioux City, Iowa, and Kansas City and St. Joseph, Missouri-are located in the humid eastern portion. Thus, all seven of the metropolitan areas in the basin proper are located on its periphery. The eleven remaining metropolitan centers in the above-mentioned ten-state area-Pueblo, Colorado, Topeka and Wichita, Kansas, Davenport (including also Rock Island-Moline, Illinois), Cedar Rapids, Des Moines, and Waterloo, Iowa, St. Louis and Springfield, Missouri, and Minneapolis (St.Paul) and Duluth, Minnesota-are also located chiefly in the humid eastern states. Three states-Montana, Wyoming, and North Dakota-have no metropolitan areas at all.

Of the sixty-seven metropolitan areas of dominance, as defined by Bogue, nine are within the borders of the basin states. ${ }^{20}$ Three of them are within the basin proper-Denver, Colorado, Kansas City, Missouri, and Omaha, Nebraska. Denver is at the breaking point of transportation over the Rocky Mountains, however, and it serves the nation, in a national sense, perhaps even more than it serves the mountain area and the Missouri River Valley; thus, it is not a truly indigenous Missouri River

\footnotetext{
${ }^{18}$ For a more extended discussion of this feature, with reference to not only the Missouri River basin, but all of the Great Plains, see KRAENZEL, op. cit. supra note 8.

${ }^{10}$ U. S. BureaU OF THE Census, loc. cit. supra note 13.

${ }^{20}$ BoGue, op. cit. supra note $I$, at I6-17.
} 
Valley city. And the humid-area orientation of Kansas City and Omaha makes of them less indigenous cities than is required if they are to function truly in the setting of the Missouri River Valley. Much the same can be said of the remaining six metropolitan centers outside the basin proper, but within the borders of the basin statesas a simple enumeration and visualization of their locations will make clear: St. Louis, Missouri, Minneapolis (St. Paul), Minnesota, Des Moines, Iowa, Wichita, Kansas, Duluth, Minnesota, and Davenport (Moline and Rock Island, Illinois), Iowa.

It would seem to be clear, therefore, that the Missouri River Valley is largely denuded of the urban, industrial, and metropolitan functions that would make it vitally competitive with other areas of the nation. Significant also is the fact that its existing metropolitan centers, as well as those that impinge on the basin from outside, are operating in the context of a humid-area psychology and social value system which they project upon a semiarid or arid land. Furthermore, these centers are in the shadow of a still larger complex of metropolitanism (Chicago-PhiladelphiaNew York City) to which they are necessarily affiliated.

Coupled with the nonindigenous fact of the metropolitan centers that serve the upper Missouri River basin is the already-noted lack of institutional and cultural adaptations or lack of suitability of the ways of living that are projected upon the upper Missouri River basin population, especially that portion to the west of the ninety-eighth meridian. To have successful institutional and cultural adaptations in the basin, there must be a reshaping of humid-area patterns to conditions of semiaridity, or invention and dissemination of new patterns that are alternatives to the imperfect and imported kinds. ${ }^{21}$ To achieve this, however, it is necessary to undertake basic research and to assume a scientific objectivity that would free the mind from humid-area bias. It is necessary, also, both to develop resources, facilities, leadership, and manpower to aid the process, and to foster an inviting climate of university atmosphere and an urban-metropolitan consciousness that would be the focal point for tolerance and promotion of such ideas.

These factors emphasize the need for true regionalism, in the widest sense. ${ }^{22}$ For, in the upper Missouri River Valley, there are obviously not enough resources and people to effect its full development, especially without indigenous cities. Other basins in the Great Plains are faced with the same problem-among them, the Rio Grande, the Brazos River, the Red River of the South, and the Arkansas River. This problem, then, broadly becomes one of Great Plains, not merely Missouri River

${ }^{21}$ For example, to have institutional stability in the area, it is necessary to have reserves, accumulated in good years, for use in years of no income. This is as true for schools, churches, towns, county and state government, business enterprises of all kinds, and all other institutions as for individuals, family living, and farm and ranch operating costs. Yet, the humid-area patterns of financing, federal taxation, banking, price-making forces, etc., do not recognize this fact. Even the present federal program of price support and production control for Great Plains wheat farmers violates, to the highest degree possible, this essential principle, the need for accumulating reserves for successful living in the area. There are numerous other basic adaptations that are also necessary-some already partially instituted, others still to be tested, and many yet to be devised, and they, too, must widely be disseminated and ingrained into the way of life.

${ }^{22}$ See KRAENZEL, op. cit. supra note 8 , cc. 25,26 , and 27 . 
Valley, significance. From this, it follows that basin development of the Missouri River may be a proper tool, but only if it is conceived as but one element of a larger over-all scheme of regionalism that is Great Plains-wide in scope. Only in this context will the social consequences of basin development be fully constructive and basically significant in the Missouri River Valley. This requires further elaboration.

A detailed study of the geography of the Missouri River Valley reveals the following aspects: The Missouri River originates in a clearly defined geographic region, the Rocky Mountains of the northern United States. After it and its major tributaries (the Yellowstone River, the Platte River, and others) leave the Rockies, they traverse the northern Great Plains, often in a northerly, then in an easterly, and finally in a southerly direction. Eventually the Missouri River itself and some of its lower tributaries enter into a third region, namely, the subhumid and humid Mississippi River Valley to the east. ${ }^{23}$ Measured in terms of the distribution of population, cities, newspapers, universities and colleges, and most other processes that affect the lives of people, the balance of the scale of values in the Missouri River Valley, too, is tipped decidedly downstream, in the humid-area direction. The lower basin, then, east from the ninety-eighth meridian, is like a funnel into which the entire upper basin is filtered and drained, and with respect to which the upper basin operates in hinterland fashion. ${ }^{24}$

Although ample factual evidence to support this conclusion can be marshalled, only two specific items will be mentioned. The so-called Missouri Compromise of I944 stipulated that the waters of the Missouri and its tributaries, west of the ninetyeighth meridian, should be used first for irrigation upstream, in the mountain and plains area, and secondarily, or later only, for downstream uses-urban and industial water supply and navigation. ${ }^{25}$ Although this scheme was ratified by Congress in 1944 , in June 1956 , the matter, in a related way, was again raised in the form of the Barrett bill, ${ }^{26}$ which was approved by the Subcommittee on Irrigation of the Senate Committee on Interior and Insular Affairs. ${ }^{27}$ Whether the Missouri Compromise of 1944 will withstand the tests of downstream pressure and still be enforced is still to be decided. The history of Missouri Compromises in the past, however, has not been reassuring.

Still another inroad-albeit largely unpublicized-has recently been made into

\footnotetext{
${ }^{23}$ See 2 President's Water Resources Policy Comm'n, op. cit. supra note 6, at 165 . The Missouri River basin proper is divided into several subareas-namely, the Rocky Mountains, the Northern Ranching Area, the Great Plains, the Black Hills, the Sand Hills, the Flint Hills, the Ozark Highlands, and the Lower Missouri Flood Plains. This does not include the areas in the ten states that are not within the basin proper.

24 There are some writers, including geographers, who deride the "hinterland" concept. Frequently residents of metropolitan centers and larger universities, they have never truly experienced the helplessness of the people who function in a hinterland role; or else they are biased against old and established facts that are not couched in current scientific language.

${ }^{25}$ Flood Control Act of 1944, 58 Stat. 889, 33 U. S. C. $\$ 701-1$ (b) (1952). See also Missouni Basin Survey Comm'n, op. cit. supra note 17 , at 159 , 198 .

${ }^{20}$ S. 863,84 th Cong., 2d Sess. (1956).

${ }^{27}$ S. ReP. No. 2587,84 th Cong., 2d Sess. (1956). See also Western Water News, Junc 1956, pp. 4, 5 .
} 
the principle of the Missouri Compromise of r944. The years 1953-54 were dry ones in the upper Mississippi River Valley-so dry that the streamflow level could not keep the salt waters of the Gulf of Mexico from threatening the water supply of New Orleans. To remedy this situation, the Army Engineers lowered the storage water level in Fort Peck Reservoir in Montana from seventeen and one-half million acre-feet to five or six million acre-feet, or by about seventy per cent. This accumulation of water in Fort Peck Reservoir had been intended to fill a large part of Garrison Reservoir in central North Dakota, following its completion. Now, with a drought in prospect in the northern Great Plains and Rockies, irrigation water is at a minimumbecause of pressure from downstream interests, not on the Missouri River, but at the mouth of the Mississippi River. ${ }^{28}$

But the issue is not even that simple. The upper Missouri River Valley is the hinterland of the so-called Twin Cities, Minneapolis and St. Paul, Minnesota, generally described as "the Northwest." It is the major revenue area for a number of railroads, among them the Great Northern, the Milwaukee, the Northern Pacific, the Burlington; and, to some extent, the Union Pacific-all leading into the Twin Cities and/or Chicago. Navigation on the Missouri River, as a facet of multipurpose river basin development, would reroute some of the payload to Kansas City and St. Louis, Missouri, and ocean-wise. So there is rivalry not only in the Missouri River Valley, but outside it, between metropolitan centers in the humid area for tribute from the upper basin. This affects some of the major economic and institutional complexes of the economy, among them wholesaling, financing, newspaper circulation, marketing, interest-taking, market manipulation, price-making and fixing, convention gathering, and governmental agency and service headquarters.

What has been said of the Missouri River Valley is equally true of the remaining Great Plains rivers, different in degree only-the Rio Grande, the Brazos River, the Red River of the South, and the Arkansas River. They all rise in the mountains, traverse the semiarid Great Plains, and empty into the humid-area portions of the states involved or into adjacent humid-area states. Thus, in Texas, a major struggle can be witnessed between the semiarid or arid and the more humid parts of that state for scarce water that is insufficient for the agricultural and the urban-industrial development that has flourished there in recent years. ${ }^{29}$ In some instances, international aspects are also involved-with Mexico, in the case of the Rio Grande; with Canada, in the case of the Red River of the North and the Belly River, a subsidiary of the Milk River which empties into the Missouri River.

And the western tier of Great Plains states-Montana, Wyoming, and Colorado particularly-are likewise drawn downstream, all the way to the Pacific, where the larger urban and industrial complexes in the Columbia River and the Colorado River basins are located. The downstream pull in these basins is gigantic, as is evidenced

\footnotetext{
${ }^{28}$ See Will Water Become Scarce? (an interview with Lt. Gen. Samuel D. Sturgis, Jr., Chief of Engineers, United States Army), U. S. News \& World Report, April 27, 1956, p. 85.

${ }^{20}$ For the details of this conflict, see Walter Prescott Webb, More Water for Texas (1954).
} 
by overappropriation all along the Colorado $\operatorname{River}^{30}$ and the proposed diversion of some of the waters of the Columbia River southward, all the way to California. ${ }^{31}$ The situation on the Colorado River has been further intensified by the construction of the Thompson tunnel in the Colorado Rockies to divert some of the water flowing westward into the Great Plains for irrigation and for urban use. ${ }^{32}$ Here, too, are international complications. The prospects are real that a great industrial and urban expansion in British Columbia will indicate the hoarding and diversion of the headwaters of the Columbia River before it enters the United States. Such waters, at the Canadian source, could readily be diverted into the Fraser River, with great benefit to Canada.

Without delving further into the details of the industrial, economic, political, legal, and governmental aspects involved, it thus becomes apparent that river basin development could easily result in further exploitation of the people and resources of the upper Missouri River Valley by the existing urban-industrial complexes that have their foci in the lower basin or outside the area; and this is also the case with the other Great Plains rivers. ${ }^{33}$ Empire building of an earlier period, accomplished by personal power and the strength of the boss on the job, has today become empire building of a more subtle type, with the aid of legal advice, public funds, manipulation of public opinion, and the help of the federal government. Where once Jim Hill built on his own, the government-business partnership deal in hydroelectric development now has recruited the taxpayers of the nation as shareholders in a venture to build private gains and power on a still larger scale. ${ }^{34}$ Instead of hydroelectric development, hospital and medical care insurance might have been cited; ${ }^{\text {ab }}$ or flood control and navigation, as practiced by the Army Engineers, might have been used to illustrate the point. ${ }^{36}$ And in the guise of national goals and objectives un-

${ }^{30}$ See 2 President's Whter Resources Policy Comm'n, op. cit. supra note 6, at 355-56, 359, 36r, $388-93,395-96,460-62$.

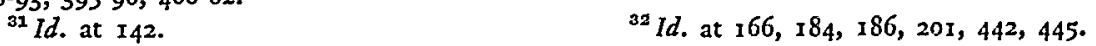

${ }^{33}$ The skeptic needs only to review the off-shore oil controversy after World War II, in which the "states' rights" issue was the blind for appropriation of the oil of the southern Great Plains by international business concerns. For more detailed discussion of the earlier part of this maneuver, see A. G. MezEnık, The Punsuit of Plenty especially c. 5 (x950). The citizenry of the more isolated northern Great Plains, with its newly discovered oil prospects in Montana and the Dakotas, had not even become awarc of its potential before they lost control of this resource. This story has yet to be written, and the records for it will not easily be found. Nor is the pattern greatly different for electric power and certain other resources of the Missouri River Valley.

at The struggle as to whether there shall be public or private power development at Hell's Canyon on the Snake River in the Columbia River basin is the more dramatic aspect of the larger struggle that is taking place in all the basins of the West, including that of the Missouri River, and in the basins of the East, as evidenced by the Dixon-Yates affair.

${ }^{\text {ss }}$ Speaking of hospital and medical care insurance, it is obvious that most such privatc plans, limited to state-wide coverage as a rule, do not have sufficient enrolment and finances to accumulate the necessary reserves that are essential for building a financially sound program that can weather scveral years of low income induced by drought combined with other hazards common in the Missouri River basin and the Great Plains generally. No way has been worked out to protect the long-time contributor who suddenly finds himself without income to pay his premiums, his taxes, his operating costs, and his family living costs in such poor years. A federal subsidy to such programs is not facing the realities of the sinuation in the Missouri River basin and the Great Plains proper.

${ }^{30}$ See Arthur Mass, Muddy Waters: The Ardy Engineers and the Nation's Rivers (1951). 
suited to Missouri River Valley conditions, dryland ranching and farming are caused to meet head-on with irrigation farming, to make the contrast between humid-area and semiarid ways of life even more striking than ever. ${ }^{37}$

The solution to this dilemma lies in an appreciation of the fact that river basin development is but one of many techniques that may be employed to unite the people and resources of a region so that they may work out their destiny in cooperation with the other regions of the nation and with the aid of the nation itself. As a means to this end, river basin development would have one fundamental advantage: as a rule, river systems traverse or touch upon several regions, and their development, thus, would force upon people and interests, whether private or public, the recognition that some population-resource development can take place only on a regional level and by virtue of cooperation between several regions. River basin development, thus, would become a strategic tool for implementing cooperation between several regions. This is, perhaps, its strongest point. ${ }^{38}$

In further support of regionalism as the ultimate solution of the problems of the upper Missouri River Valley and the Great Plains as a whole, several other considerations should be kept in mind. For one thing, the states-especially Montana, Wyoming, Colorado, and New Mexico-now pulled in at least two directions by strong basin development, need to find a basis of unity. This is also true of the eastern tier of Missouri River Valley states-North and South Dakota, Nebraska, and Kansas -which are pulled Missouri River basin-ward for some of their interests and humid area-ward for other of their interests. So, too, with Oklahoma and Texas. It would appear that regionalism, conjoined with river basin development, would be best suited to assist in creating this necessary unity. Then, basin development could do its more limited job, regardless of the region the river system traverses.

The Missouri River Valley and the Great Plains, moreover, are generally inhabited by residents who think, and act, and live as minorities. This is because of lack of adequate transportation and communication within the area and because of lack of region-centered solutions of the basic difficulties in the area. This failing is compounded by the torn-apart allegiance of the residents to various centers and interests outside the region. These minority-group attitudes and modes of behavior . are, in a measure, the expression of people who cannot resolve their problem situations and see little prospect of doing so. Their frustrations find release in striking out at other people and situations, at random, or in withdrawal behavior. ${ }^{39}$ Basin develop-

\footnotetext{
${ }^{37}$ The arid regions of the nation (the Rocky Mountain and Intermountain West) have an oasis type of settlement. Agricultural people live in irrigated areas and use the surrounding land in conjunction with the irrigated base. But in the semiarid Great Plains, people live all over the land, including the dryland. Relatively speaking, irrigation development is insignificant in size and scope. Hence, irrigated farmers live next to areas where dryland farmers and ranchers live, and except where there is purposeful integration between dryland farming and ranching, on the one hand, and irrigation, on the other hand, there is a decided contrast between these two types of settlement. An increase in irrigation can only emphasize this contrast and distinction and the misunderstandings and problems that flow therefrom.

${ }^{38}$ See Kraenzel, op. cit. supra note 8 , cc. 26 and 27.

${ }^{30}$ For an analysis of this feature with respect to the Great Plains, see id., cc. 17-20. Not only nationality and racial groups comprise these minorities; farmers, ranchers, businessmen, laborers, profes-
} 
ment alone offers little prospect of remedying this minority-group psychology in the upper Missouri River Valley. In fact, the likelihood is that this characteristic will become more intensified as the people and interests of the different areas in the basin consequently come into more frequent and intimate contact, and as the differences between unintegrated dryland, on the one hand, and irrigation development, on the other, become more pronounced by virtue of this closer relationship. Only in the context of regionalism, with its attendant increased opportunity for effective participation in policy-making matters, can river basin development assist in resolving this minority-group conflict in the region.

Nor will basin development, without the aid of true regionalism, avoid the increased social cost of space in much of the upper Missouri River Valley that stems from the great distances and scattered habitation and the growing loss of population in many areas of the basin. ${ }^{40}$ This problem cannot be met except with increased subsidy or by postponing services; and the latter alternative usually results in higher rehabilitation and relief costs at a later date. Accompanying this phenomenon of the increased social cost of space is the fact that the fewer residents who remain may have higher individual and personal incomes, but these higher incomes cannot necessarily support the basic institutions under conditions of overly sparse population. Associated also are other social facts, such as a psychology of resources exploitation, a philosophy of temporary residence, an excessive population mobility and loss, a general underdevelopment of the community, ${ }^{41}$ and fewer social opportunities, so that people find it more difficult to achieve well-rounded experiences for effective leadership and personality development. ${ }^{42}$ There is little that river basin development alone can do to resolve or mitigate these problems.

Finally, the inadequacy of river basin development as a solution of the problems of the Missouri River Valley is exacerbated by the unguided and uncoordinated nature of the existing program. The Inter-Agency Committee has no power to integrate the efforts of separate agencies; ${ }^{43}$ it is not an official committee with authority truly to represent the residents of the area; ${ }^{44}$ and it has no way of working with these residents. It has been said that "few local people have ever appeared on the committee's program, and an examination or the minutes indicates no local

sional people, management groups, and others, too, band together and exhibit behavior that bears the stamp of a minority-group psychology of a basic and debilitating order. The Indian minority, which is sizable in the upper Missouri River basin, is extensively exploited by the other minorities of the basin, and such exploitation varies in intensity with the struggle for the advantages hcralded by basin development. See id. at 72-90, 238-42. But, except for its more extreme aspects, the Indian minority role is not fundamentally different from that of the other minority groups in the basin. For a more detailed analysis of the Indian problem in the basin development of the Missouri River, see Frances Cusuman and Gordon McGregor, Harnessing the Big Muddy (1948).

${ }^{10}$ See Kraenzel, op. cit. supra note 8, at $201-06$.

21 See Carl F. Kraenzel, Montana's Population Change, 1920 to 1950 (1956), which contains data not only for Montana, but for states adjacent to it.

${ }^{13}$ See, e.g., Frank Aiexander and Carl F. Kraenzel, Social Organization of Sweet Grass County, Montana (1953).

${ }^{43}$ See Missouri Basin Survey Comm's, op. cit. supra note 17 , at $85-86$.

1 Ibid. 
group or person has made protest before the Inter-Agency since June I950."45

It is apparent, then, that there has not been the coordination among governmental units in the Missouri River Valley that there has been in the Tennessee River Valley. There has been neither the devoted leadership of a Lilienthal or a Clapp and others to make democracy work from the grass-roots level, nor the help from the outside to make communities grow-help in the form of guidance, leadership encouragement, organizational integration and coordination into larger areas of interaction, townbuilding for permanent living, research, and information-gathering and dissemination for the solution of local problems. And, above all, there has not been the development of a similar psychology of optimism and growth for individuals and groups in the region.

\section{IV}

\section{Conclusion}

A major hypothesis of this paper has been that the concentration of population in metropolitan areas that are also the foci of our peculiar urbanized, commercialindustrial economy has been increasing, and this has been accompanied by a reaching out for more and more hinterland area. The task ahead, accordingly, is to perfect and introduce the necessary organization that will make of both the center of dominance and the hinterland area a unit of democratic participation, thus injecting into their government an element of greater social justice.

Such a scheme of organization, itself a social consequence of no small significance, is associated with other social consequences which, in the Tennessee River Valley, have been, in considerable measure, the result of basin development under an enlightened administration. The Tennessee River Valley, however, is a small basinDavid E. Lilienthal described it as sufficiently small so that the benefits of the TVA program could reach all the people in like democratic fashion. ${ }^{46}$ And there were other favorable conditions: the basin has several indigenous metropolitan centers of dominance; it has easy access to the entire urbanized, commercial-industrial complex of the East; and it is blessed with high and seasonably favorable precipitationall of which constitute the ethos of the culture of the nation. From this, it is clear that basin development in the Tennessee River Valley, involving financial contributions from the nation as a whole, could not help but produce socially beneficial consequences of considerable proportions.

In the larger western basins, however, such as that of the Missouri River, where the milieu is considerably different, the same social consequences have not followed upon developmental activity. These basins are considerably larger than that of the Tennessee River and contain a greater diversity of resources and social phenomena. They also have fewer indigenous metropolitan centers of dominance, and those that do

\footnotetext{
${ }^{45} \mathrm{Id}$. at 86.

${ }^{40}$ He states that, in his opinion, the Tennessee River basin is as large as any basin or regional program should be in order to maintain the grass-roots-like and democratic spirit that is basic to such development. Lilientral, op. cit. sttpra note II, at 154 .
} 
exist tend to be located on the periphery or even outside of the basins proper, where they serve national and international interests, rather than those of the basin or the region. Furthermore, in the West, there is a need for basic institutional adaptations to the facts of semiaridity and aridity-adaptations for which there is now little tolerance in the ethos of the national culture. Such adaptations on all levels of living, including industry and business, financing and management, public agency and governmental operations, school and church organization, town-building and community organization, as well as agriculture, must have a focus in the area concerned and must have the functional dynamics that metropolitan centers of dominance can offer.

It is the conclusion of this writer that river basin development, alone, even optimally administered, is unequal to this challenge in the West. These are rather the tasks of true regionalism-not regionalism with hard and fast lines, like state and local government, but regionalism that is boundaryless and that emanates from indigenous metropolitan centers of dominance. This regionalism must serve as a form of social organization to foster democratic participation between the hinterland area and indigenous metropolitan centers of dominance; and it must proceed simultaneously with, if not before, river basin development. Thus only can river basin development be properly channeled and the existing hinterland be saved from still further exploitation by the urbanized, commercial-industrial complex that now has its roots in nonindigenous metropolitan centers of dominance.

River basin development, in basins that traverse several regions, then, is primarily that institutional device by which the seeds of interregional cooperation can be planted and nurtured. This is the distinctive contribution of significant social consequence that river basin development can make to the West; and this may eventually be its role in the smaller eastern basins, too, after it is found necessary to recruit regionalism to bring social justice to hinterland-metropolitan relationships there as well. 